\title{
THE POLITICAL ROLE OF THE FREE UNIONS AND THE FAILURE OF COUNCIL GOVERNMENT IN HAMBURG NOVEMBER, I9I 8 TO MARCH, I9I9
}

It is, perhaps, all too easy for the student of German political history to adopt the device of speaking of events in the capital city as if they could be taken to represent developments occurring on a national scale. ${ }^{1}$ But it is far less accurate to use Berlin in this way than it is to use, for example, Paris or London. For one must keep in mind that the federal structure of Germany was by no means a mere legal fiction. Local political issues and the local organizations of the national parties retained considerable importance throughout the Weimar period. Indeed, one could well argue that in a number of instances, especially in the early years of the Republic, local political struggles were decisive for the formation of national policies.

As the recent study by Eberhard Kolb ${ }^{2}$ rightly emphasizes, the importance of local developments was particularly marked during the formative period of the Weimar Republic, from November, I918, through the spring and summer of I9I9, and especially as regards the much disputed "council movement" (Rätebenvegung). Although the ideological roots of this system for the reorganization of German political life through the institution of a hierarchy of elected corporative bodies extend well back into the nineteenth century, its tangible roots were in the spontaneous workers' and soldiers' councils of November, 1918.3 These councils already existed in many areas,

\footnotetext{
${ }^{1}$ I wish to express my gratitude to the Penfield Foundation, the Social Science Reseatch Council and the Hoover Institution for their support of the research on which this article is based.

The abreviations used in this article are as follows:

ADGB Allgemeiner Deutscher Gewerkschaftsbund (Free Unions)

KPD Kommunistische Partei Deutschlands (Communist Party)

SPD Sozialdemokratische Partei Deutschlands (Majority Socialists)

USPD Unabhängige Sozialdemokratische Partei Deutschlands (Independent Socialists)

2 Die Arbeiterräte in der deutschen Innenpolitik, 19 18-19 (Düsseldorf, I962).

${ }^{3}$ See, for example, Walter Tormin, Zwischen Rätediktatur und Sozialer Demokratie (Düsseldorf, 1954), pp. 9-21.
} 
such as Hamburg, before the revolution really got under way in Berlin. The councils, therefore, were a "given" to national leaders, and the question was not whether to create them, but whether they were to remain and if so in what form. To a considerable extent, the answers to these questions were provided by developments in Hamburg, Bremen, Munich and elsewhere. If the council governments had proved viable where they were established, national leaders would have been forced to take the demands for the reorganization of German politics along the lines of a council system a good deal more seriously than they did. ${ }^{1}$

The history of the council movement, therefore, must not be limited to the views of national leaders on the subject, but must be based upon a careful consideration of the various attempts at council government throughout Germany. What chance did the council governments have of success? How wide was their support and from whence did it come? Why did they fail?

In this paper, we shall examine some aspects of the revolution as it developed in Hamburg, the second largest German city, with the intent of providing at least partial answers to these questions. In Hamburg, we have an instance in which a Council Government achieved control over a city-state and remained in power for several months. ${ }^{2}$ The Hamburg labor movement, moreover, was particularly well-developed, with a flourishing cooperative movement in addition to a very large and effective trade-union organization and one of the strongest Socialist parties in Germany. ${ }^{3}$ Hamburg, consequently, provides a particularly striking case in which the development of the council movement may be studied, with particular reference to the interaction of labor union and socialist party in regard to the councils.

Reports of the formation of workers' and soldiers' councils in Kiel appeared in the Hamburg papers on the morning of November s, 1918, having an effect, according to one observer, "like a thunderbolt". 4 Before noon, a strike, completely unauthorized by the trade unions, had broken out in the shipyards and spread rapidly from one yard to the next. By early afternoon, representatives of the harbor workers

${ }^{x}$ In this connection, it is important to keep in mind that, prior to the framing of the Weimar Constitution, it was widely believed in Hamburg and elsewhere that the form of local government in Germany would continue to be for the Länder to decide. It was, of course, one of the major innovations of the Constitution that it enumerated nationwide specifications for the Land governments. See Article 17 of the Weimar Constitution. 2 The city government of Hamburg was also the government of the Land Hamburg.

${ }^{3}$ Hamburg was usually referred to as the "Hauptstadt des deutschen Sozialismus". See, for example, Richard Bünnemann, Hamburg in der deutschen Revolution von I9I 819, unpubl. diss., Hamburg, 195 I, p. 28.

"Gertrud Bäumer, "Heimatchronik", in: Die Hilfe, Nr. 46 (Nov., 1918), p. 540. 
were meeting in the Union Hall discussing the calling of a general strike in Hamburg in support of the revolt in Kiel. ${ }^{1}$

Apparently surprised by the turn of events, the leaders of the established labor movement (SPD and Free Unions) attempted to stall for time. An SPD representative proposed a motion at this first revolutionary gathering on the afternoon of November $s$ calling for the postponement of any further action until a meeting of all labor representatives could be held two days hence. This motion was passed by a bare majority. ${ }^{2}$

Later that evening, the Independent Socialists (USPD) held their first open meeting in Hamburg. It was attended by some five to six thousand workers and organized primarily by Wilhelm Dittmann, USPD leader from Berlin and soon to enter the first republican government of Germany. The results of this meeting were rather different from those of the SPD-dominated meeting earlier that afternoon. A series of overtly revolutionary proposals were adopted unanimously: workers' and soldiers' councils should be formed at once; the workers of Hamburg should go out on general strike in support of the socialist revolution. ${ }^{3}$ But the USPD leaders, having seized the initiative from the hesitant hands of the SPD, were soon to have it seized from them in their turn.

During the night of November 5, Friedrich Zeller, a young sailor with a rather checkered background, ${ }^{4}$ found his trip to Kiel to rejoin his naval unit interrupted. The trains between Hamburg and Kiel were no longer running because of the revolutionary disturbances. Gathering around him a knot of similarly stranded sailors, Zeller marched on the harbor. There, he and his cohorts seized a number of small naval vessels and procured a substantial supply of arms. By morning, Zeller's little band, representing no party whatsoever and having multiplied a hundredfold, was firmly entrenched in the Union Hall and had occupied the main train station. ${ }^{5}$ After a short but sharp gun-battle in which several lives were lost, Zeller and his followers then gained control over the most important military concentration in the city, the barracks of the Seventy-Sixth Regiment. ${ }^{6}$

${ }_{1}$ Paul Neumann, Hamburg unter der Regierung des Arbeiter- und Soldatenrats (Hamburg, I9r9), p. 62. This is the most reliable account of the revolution in Hamburg, by a participant.

${ }^{2}$ Sozialdemokratischer Verein für das hamburgische Staatsgebiet, Jahresbericht der Landesorganisation, Jahrgang I914-I9, p. Io (hereafter cited as SPD-Hbg, Jbrt. 1914-19);

Neumann, p. 3.

${ }^{3}$ Neumann, p. 4.

4 For Zeller, see Bünnemann, p. 75.

5 Bünnemann, pp. 75-8; Neumann, p. 5.

6 SPD-Hbg, Jbrt. I914-19, p. 10; Neumann, Pp. 6-7. 
By the morning of November 6, the revolution in Hamburg was decidedly under way, without any effective political leadership as yet having been established. The USPD leaders were quick to fill the gap. With crowds of workers milling in the streets of the city, Hans Kalweit, a USPD leader, hastened to draw up the first revolutionary handbill. The demands stated were essentially the same as those adopted by the USPD meeting the night before. ${ }^{1}$

The issuance of this proclamation marks one of the focal points of the revolution. It was signed by Kalweit for the "Workers' Council" and by Zeller for the "Soldiers' Council."2 The principal institutions of the revolution were in existence, at least on paper. Moreover, the USPD was now clearly in control. Although Zeller's name appeared on the proclamation, Kalweit was the dominating figure, and Zeller was to be replaced a day or two later with another USPD representative. ${ }^{3}$ Finally, the proclamation was printed on the presses of the Hamburg SPD organ, the Echo. Realizing that their move to gain time had failed, the leaders of the Hamburg SPD, Otto Stolten and Heinrich Stubbe, had gone off to Berlin to seek advice from the party chiefs. Before leaving, they had left word that the Ecbo should be put in the service of the movement if it appeared that the SPD was losing control, probably with the idea that it would soon be seized anyhow. ${ }^{4}$ This order had been carried out just prior to the publication of the handbill. ${ }^{5}$

The initial stage of the revolution was now nearly complete. All that remained was a formal confrontation with the established government. This was accomplished on the evening of November 6 . After an enthusiastic open-air meeting, the leaders of the USPD, at the head of an armed band, burst in upon the traditional Thursday evening meeting of the Bürgerschaft, the Hamburg parliament. ${ }^{6}$ There they demanded and received recognition as representatives of the Workers' and Soldiers' Councils and obtained a statement that the Hamburg Senate (the Land government) was "ready to serve the new times and the new conditions". ${ }^{7}$ Having gained de facto recognition by the executive branch of the Hamburg government, the USPD was now at least formally in control of the city.

The party then turned to the problem of solidifying its position. The first step would be to organize the Workers' and Soldiers'

1 Neumann, p. 7 .

2 Ibid., p. 8.

3 Ibid., p. 2 I.

4 SPD-Hbg, Jbrt. I914-19, p. I I.

5 Neumann, p. 7.

6 Ibid., p. 12.

7 Ibid. 
Councils. For this purpose, a meeting of the leaders of the various sections of the Hamburg labor movement, including the Free Unions, was held on November 7 to determine the manner of election of the councils. This was something of a touchy problem in view of the fact that the SPD leaders could see no reasons for electing councils at all. All that remained, from their point of view, was to elect a new Bürgerschaft on the basis of free, universal suffrage. And a very temporary provisional government would serve for the purpose of holding elections. ${ }^{1}$ The SPD, however, was in no position to enforce its will, and the party leaders finally agreed to a compromise in the manner of election which they believed would provide them with a controlling position in the Executive of the councils. This belief, as the report of the SPD points out, "was an illusion".2 For when the results were in, the left wing of the Hamburg labor movement was clearly in control, as was quickly demonstrated in the election of a chairman of the Executive. The choice was Heinrich Laufenberg, earlier leader of the left wing within the SPD in Hamburg and later National Bolshevist, who had arrived in the city only on November Io and by the in th was directing the revolutionary government. ${ }^{3}$

From this time forward, there is a perceptible pattern in the development of the revolution. From November i i on, there were two governments operating in Hamburg side by side. The Council Government, headed by Laufenberg, was ostensibly in control. The Senate and Bürgerschaft, however, continued to function alongside the councils and, indeed, retained de facto control over finances. 4 The actual governing power of the Council Government was not extensive. While it retained a theoretical veto power, the lack of specialized personnel made it virtually impossible to keep tabs on the day-to-day operations of government. ${ }^{5}$

Even though Laufenberg had agreed as early as mid-November to

1 See the statement of Carl Hense (SPD) in the negotiations between the representatives of the Senate and those of the Workers' Council on Nov. I6, 1918, in: Wörtlicher Auszug aus dem stenographischen Protokoll, reprinted in: Walther Lamp'l, Die Revolution in Gross-Hamburg (Hamburg, I921), pp. 95-IOI.

2 SPD-Hbg, Jbrt. 1914-ז9, p. 14.

${ }^{3}$ For Laufenberg, see Otto E. Schüddekopf, Linke Leute von Rechts (Stuttgart, 1960), p. 108n; Ruth Fischer, Stalin and German Communism (Cambridge, Mass., 1948), pp. 92-3; Kolb, pp. I49-50. Schüddekopf mistakenly associates Laufenberg with the outbreak of the revolution in Hamburg, p. I00. Compare Neumann, p. 21.

4 Arbeiter- und Soldatenrat Gross-Hamburg, Protokolle, I918-19, Nr. I, Bd. I (unpubl. doc., Hamburg Staatsarchiv); see also, Lamp'l, pp. 95-109.

5 Carl August Schröder, Aus Hamburgs Blütezeit, Lebenserinnerungen (Hamburg, 192 I), p. 345 ; Ferdinand Vieth, Siebzehn Jahre Handelsgesellschaft Produktion mbH. zu Hamburg (Hamburg, 1930), p. 221. 
the election of a new Bürgerschaft by April I, the future role of the councils was by no means clear. He had certainly not agreed to their dissolution. The SPD, consequently, was rather less than satisfied with the prevailing situation. For the position of the Council Government, whatever its limitations from the standpoint of government, had decided advantages from the standpoint of marshalling popular support, especially among labor. The one branch of government in which Laufenberg was really effective was the Labor Office, and through the powers of that office, he was able to intervene in industrial disputes and other labor matters in such a way as to consolidate a basis of support for his government. ${ }^{1}$ It was feared that he would be able to win sufficient support to continue the councils in existence, in some capacity or other, even after the election of the new Bürgerschaft. This the SPD decidely wished to avoid, for reasons which will become clear presently.

The Hamburg SPD organization accordingly took up a position in opposition to the councils immediately after their election on November Io, demanding new elections to the councils and an early election of a new Bürgerschaft. ${ }^{2}$ Failing in these respects, the strategy of the SPD was very similar to that of their colleagues in Berlin. Along with leaders in the Democratic Party and others desiring the establishment of a liberal, democratic republic (or at least the demise of the councils) the Hamburg Social Democrats concentrated their attention on the Soldiers' Council. It was hoped that if control could be won over this central organ of military power, it would be possible to undermine the position of the Laufenberg Government. ${ }^{3}$

The Majority Socialists pursued this policy throughout the hungry and cold winter of I9I8-I9 with considerable success. In spite of attempts by Laufenberg to reform the police organization, the Social Democrats gained increasing power in the Soldiers' Council until, by mid-January, it became apparent that the Council Government had almost no control over its police forces. As the various crises of December and January led to one mass demonstration after another, control over the streets increasingly slipped into the hands of the Social Democrats and their allies. ${ }^{4}$ Finally, on January ig (the day before the election to the National Assembly), Laufenberg and his colleague, Dr. Herz, Minister of Justice, resigned. "The Workers' Council", Herz wrote, "is powerless. Hamburg is under the dicta-

${ }_{1}^{1}$ Heinrich Laufenberg, Die Hamburger Revolution (Hamburg, I 919), pp. 8-9, I3-1 s.

2 Neumann, p. 22.

${ }^{3}$ Frederick-Segel Baumann, Um den Staat: Ein Beitrag zur Geschichte der Revolution in Hamburg (Hamburg, 1924), p. 39.

4 Neumann, p. 129. 
torship of the Soldiers' Council."1 The Council Government, accordingly, passed entirely under the control of the Majority Socialists and was allowed quietly to wither away. There remained only a formality on March 26 when the Social Democratic Chairman of the Executive of the councils turned over the governing power to a Social Democrat controlled Bürgerschaft, and the red flag was lowered from the Rathaus roof. $^{2}$

With this sketch of the history of the Council Government in Hamburg in mind, let us now turn to the question concerning the reasons for its failure and its possibilities for success. It should perhaps be pointed out at the outset that there is no evidence to substantiate Laufenberg's claim that he was brought down through the betrayal of the Ebert-Scheidemann Government in Berlin. ${ }^{3}$ As far as effective governing power was concerned, Laufenberg had had to concede failure long before the SPD in Berlin was in a sufficiently strong position to do him much harm. Berlin, moreover, had continued to recognize the Council Government as the ruling authority in Hamburg throughout November and December and only ceased to do so when the Majority Socialists were in control in Hamburg. ${ }^{4}$

The failure of the Council Government can be traced to its own weaknesses. It lacked trained personnel to run the governmental machinery. And, more serious, it lacked the necessary funds to carry on the tasks of administration. Consequently, as early as November i 8, Laufenberg had been forced to turn to Hamburg businessmen for financial support, much to his own disadvantage. In exchange, he had to sacrifice much of his own power and accede to the re-election of the Bürgerschaft in March or April. ${ }^{5}$ And, most important, the Laufenberg Government commanded neither sufficient popular support to rule democratically, nor sufficient military strength to rule dictatorily. ${ }^{6}$

Nevertheless, it seems clear that if the Council Government had had

1 Hamburger Volks-Zeitung, Jan. 21, I919, p. 2.

2 Neumann, p. 129.

${ }^{3}$ Laufenberg, p. 19 .

4 Laufenberg, for example, did represent Hamburg at the Conference of the German States in Berlin, Nov. 27, 1918. (Lamp'l, p. 23), but at the second conference in January, 1919, the Senate sent a representative. See Reichskanzlei, Akten betr. Hansestädte,

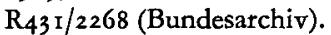

5 The proclamation of November I 8 is reprinted in Lamp'l, p. I9. Kolb, whenever he deals with the Council Government, seems to assume that it was in full control until March, rgig. See, for example, pp. 293n, 295-6.

- In the elections to the National Assembly, held the day after Laufenberg resigned, the USPD won only 7 per cent of all valid votes cast in the city, as compared to 5 I per cent for the Majority Socialists. 
the full support of the SPD, including its financial capabilities, its body of trained administrators and its stock of "good will" in the city, it could have been made to work. The question, accordingly, is why this support was not forthcoming.

There were, of course, some very good party-political reasons why the SPD could be expected not to be very enthusiastic about the council system. On the one hand, it was apparent that there was considerable enthusiasm among the working classes for the council idea. So much so, that it seemed impossible simply to ignore the movement altogether. On the other hand, the SPD could have little to gain from the formation of such councils. The parallel thus drawn with the Russian Revolution might well frighten the conservative middle classes of Hamburg, among whom the SPD was already gaining considerable support and hoped to gain still more. On the basis of its earlier electoral successes, moreover, the party could reasonably expect that Hamburg would vote heavily in its favor in a normal democratic election. The outcome of a council election, especially one conducted under the control of the USPD, would be much less certain.

While few would question the immediate expediency of the SPD's opposition to the council movement, one might well question the long-range wisdom of this policy. Numerous historians, in criticizing the opposition of the SPD national leadership to the councils, have argued that the SPD should have been prepared to abandon its possibilities for middle-class support, should have adopted the council idea and become a true reforming party, firmly based on a more predominantly labor electorate. Not only, it is argued, could the councils have provided a form of government more in harmony with Germany's needs at the time, but real, basic reforms could have been carried through. Most important, perhaps, the new government could thus have obtained a meaningful focus, a unifying spirit even, which the Weimar Republic so manifestly lacked. But, it is frequently maintained, the leaders of the SPD lacked the breadth of vision required to adopt the council idea, and the opportunity was consequently let slip. ${ }^{1}$

In attempting to evaluate this suggested alternative to the SPD rejection of the council idea, one must first, of course, establish its feasibility. Would it, indeed, have been possible for the SPD to marshal sufficient labor support behind the council system to continue

\footnotetext{
1 See Arthur Rosenberg, A History of the German Republic (London, 1936), Pp. 19-34; William Harvey Maehl, "Recent Literature on the German Socialists, 1891-1932", in: Journal of Modern History, XXXIII, 3 (Sept., 196I), pp. 302-3; Eberhard Kolb, op. cit., pp. 4०4-9.
} 
in existence as a major party while working for the implementation of the council idea? To answer this question, as far as Hamburg was concerned, we must consider the significance of the council movement for the labor movement as a whole.

For some time before the First World War, the Hamburg labor movement, like that of all Germany and, indeed, of every major industrial nation, had been sharply divided on the question of craft, as opposed to industrial, organization. ${ }^{1}$ This division became more important shortly before and during the war as the industrial unions expanded very rapidly and their leaders came to feel ever more acutely the disproportion between the unions' size and their voice in the ADGB. For, during the period in which the industrial unions had been growing very rapidly especially in the transportation and metal industries, the basic organizational form of the ADGB had remained unaltered. The most important leadership positions were most often passed along on the basis of seniority and, as a result, tended to remain in the hands of the traditional craft unions. ${ }^{2}$

This control over the ADGB by the craft unions was very much heightened by the growth of a large paid bureaucracy, since these jobs were usually filled by appointment rather than election. ${ }^{3}$ The effects of such control could be very great in the German trade union movement since there was a high degree of centralization, and local leadership councils were frequently appointed by the national leadership, sometimes without consultation with the local membership. ${ }^{4}$

All of these factors, taken together, had led to a rising opposition in the industrial unions. There was a feeling that these very large unions were in some ways subject to the much smaller craft unions, that the industrials had far too small a role in choosing the leadership and that, for example, strike policies were more often decided on the

${ }^{1}$ This subject is treated in detail in Richard A. Comfort, The Politics of Labor in Hamburg, 1918-26, (Princeton Ph. D. diss., 1962), available through University Microfilms. 2 At a time when the industrial unions accounted for over 40 per cent of the total membership of the Hamburg ADGB, almost all of the top leadership positions were held by members of craft unions; of fifty-two secondary positions on which information is available, only nine wete held by members of industrial unions. Compare the membership of the Executive Committee of the ADGB-Hamburg as given in the "Anbang" to each Jabresbericht, 1920-24.

${ }^{3}$ See Robert Michels, Political Parties (New York: Dover, 1959), pp. 142-55; Schorske, pp. 260-62. Compare also the autobiographical novel by Willi Bredel, Maschinenfabrik N\&K (Berlin, I960), pp. I31-5.

4 Philip Koller, Das Massen- und Führerproblem in den Freien Gewerkschaften. Ergänzungsheft XVII zu Archiv für Sozialwissenschaft und Sozialpolitik (Tübingen, 1920), pp. 49-50. 
wishes of the relatively well-off trades, without consideration of the problems of the industrial workers. ${ }^{1}$

Resentment against the organizational form of the unions was manifested in demands for the organization of more industrial unions, for the reorganization of the ADGB in order to give such unions more scope and a widespread movement for "increased trade union democracy", i.e., an increase in the number of elective posts, decentralization and so on. ${ }^{2}$

This opposition was much heightened by the war-time policies of the ADGB. The pressure for ever-increased production presented startling organizational opportunities for the unions through cooperation with business and military leaders. In exchange for certain regulatory duties, the ADBG was allowed, even invited, to form unions in previously resistant areas. The organizational gains were indeed great, but the unions could then be accused like the SPD of "militaristic" and "pro-war" tendencies. ${ }^{3}$

The war-time policies and gains of the ADGB were to some extent to be continued through the "November Agreement" between business and union leaders, ratified in November, 1918." Setting national standards on many important labor issues, the Norember Agreement could well be considered one of the great union gains in the history of German unionism.

But the blessings of the agreement were decidely mixed. For, in agreeing to its provisions, the union leaders had had to accept some major limitations on the manner in which strikes could be called and conducted, the techniques of plant organization and on the scope of negotiation between workers and management. With all its advantages, consequently, the November Agreement brought with it the disadvantage of laying the ADGB open to attack from the left for "selling out" to the bourgeoisie on important labor issues. Union leaders, moreover, now felt very acutely the necessity of retaining firm control over their membership so that the agreement should not be broken. This was made more difficult by the fact that, while member-

1 Schorske, pp. 260-2; Michels, p. I44n; Robert Dissmann, "Berufsverbände oder Industrieorganisation", in: Correspondenzblatt der Generalkommission, Jg. 32, Nr. 24 (June 17, 1922), pp. 335-6.

2 "Politische Gewerkschaftszerstörung", in: Correspondenzblatt, Jg. 29, Nr. 4o (Oct. 4, x9I9), pp. 46I-3.

${ }^{3}$ For the development of the trade unions during the war, see: Paul Umbreit, Die deutschen Gewerkschaften im Weltkrieg (Berlin, I928); Nathan Reich, Labor Relations in Republican Germany (New York, 1938), pp. 222-4; Gerald Feldman, Army, Industry, and Labor in Germany, 1914-18 (Harvard Ph. D. diss., I963).

4 The November Agreement is given in full in Ludwig Preller, Sozialpolitik in der Weimarer Zeit (Stuttgart, r949), pp. 53-4. 
ship was indeed bounding upwards at an almost unbelievable rate, the new members were to a very great extent in precisely those unions in which opposition was greatest: the Metalworkers, Factory Workers, Transport Workers and Textile Workers. By 192I, for example, the membership of the ADGB-Hamburg had increased ros per cent over 1914 to $243,971.1$ These four unions alone accounted for over 52 per cent of the increase. ${ }^{2}$ With the membership increases, consequently, the problems of dealing with the opposition to the established union leadership increased apace, as did ADGB hostility to industrial unionism.

The bogey of the union leaders, of course, was the threat that the split in the SPD would be carried into the ADGB, thereby greatly decreasing the unions' effectiveness. There had been, before and during the war, a rather high degree of identity between the left wing opposition in the SPD, which became the USPD, and the opposition in the unions. ${ }^{3}$

The importance of the opposition to the ADGB was not clearly appreciated in Hamburg before the outbreak of the revolution. As long as the war was in progress, the various currents of opposition could find little means of expression. The activities of opposition groups were severely limited by the war-time restrictions on "political activity", and the integration of the unions into the war-effort made the formation of opposition unions virtually impossible. Many labor leaders, moreover, were gone from the labor scene during the war years.

But on November 5, the first day of the revolution in Hamburg, it became quite apparent that the unions had real trouble on their hands, and that the degree of control they exercised was very much less than had been thought. The strike which broke out in the harbor and spread swiftly throughout the city on that first revolutionary day was conducted entirely without the collaboration of the Hamburg-ADGB organization. The urgings of ADGB leaders to return to work, moreover, went largely unheeded. ${ }^{4}$ Later that evening, at the meeting called by the Independent Socialists, the crowd was prevented only with difficulty from doing serious harm to one of Hamburg's leading trade-union officials, who had simply stopped by to see what was

1 ADGB-Hamburg, Jahresbericht 1914, Pp. 32-3 and 1921, pp. 60-3.

2 ADGB-Hamburg, Jbrt. 1921, pp. 60-3.

3 Bünnemann, pp. 53-4; SPD-Hamburg, Jbtt. I914-I9, p. 9; Senat-Kriegsakten, Z.III.n, "Berichte des Korps Lettow-Vorbeck über die politische Lage in Hamburg" (Hamburg Staatsarchiv).

4 Neumann, p. 18 ; Baumann, p. 19. 
going on. Cries of "traitor" and "war monger" greeted him from every side. ${ }^{1}$ The meeting, it will be recalled, then went on to pass a resolution demanding, among other things, the formation of workers' and soldiers' councils. The wording of this resolution provides clear evidence of the unpopularity of the trade-union leadership among the revolutionaries. "No official of the trade unions or cooperatives", it stipulated, "shall take part in the formation of the councils." mention was made, it should be pointed out, of excluding the Majority Socialist leaders.

There is no evidence to show that the union leaders were terribly worried about this show of opposition. Apparently, like most Majority Socialists, they believed that the radicalism was really inspired by only a very small group and would soon pass. ${ }^{3}$ Contrary to what had been hoped, however, the first burst of animosity against the union leadership did not lessen as the months wore on. Indeed, under the encouragement of the USPD leaders, it thrived and flourished.

Throughout November, December and January, Trade Union Hall was a frequent target for leftist demonstrations. On one occasion the building was completely occupied by demonstrators, the union officials expelled, and the treasury of the unions seized and put under lock and key. ${ }^{4}$

The most disturbing aspect of the opposition as far as the unions were concerned, was the manner in which dissatisfaction with some specific union policy increasingly tended to merge with the political opposition to the SPD and end up by striking at the unions from two directions at once. On January 9, 1919, for example, there was a great strike and demonstration led by the harbor workers in opposition to the use of the piece-work system in a number of plants. Before the war "Akkord ist Mord" (piece-work is murder) had been a slogan of the Free Unions in Hamburg, and most trades no longer worked under the system. ${ }^{5}$ The union leaders, however, in agreement with the SPD informed the workers that the requirements of rebuilding Hamburg's economy would not allow the fulfillment of their demands. ${ }^{6}$ Dr. Laufenberg, on the other hand, who not only opposed the SPD but worked against the unions in a variety of ways, supported the harbor workers. The result was the demonstration against the unions and the SPD and for Laufenberg and his anti-union policies. ${ }^{\text {? }}$

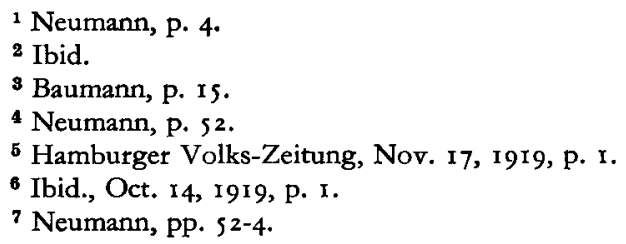


These examples of the manifestations of hostility in the labor movement to the union leadership are sufficient to indicate that this hostility was a major factor in the revolution. It remains to show the connection between the opposition to the ADGB and the council movement.

At first, during the early days of the revolution, it was believed by some, especially in the left wing of the USPD, that it would be possible actually to govern Germany on the basis of the councils from November, I9I 8 on. But Dr. Laufenberg in Hamburg and his colleagues in Berlin very soon discovered the impracticability of this objective - at least for the immediate future. Thereafter, the issue was whether the council system might not continue to exist alongside a parliamentary system. This was an issue which largely concerned the labor movement and, indeed, served to embody every one of the major disputes then current among the working classes.

The proponents of the councils tended to view them as a nostrum for all the ills of the working classes. First of all, since the Councils were to be organized in the plant, they would serve to eliminate the craft-concept from the labor movement. The basis of labor organization would be the industry, and no distinction would be made between skilled (or craft) workers and the semi- or unskilled. Democracy would be restored in the movement since the plant organizations would directly elect delegates to represent them in the district, and hence in the national economic council, where general economic and social policies would be negotiated with industry and government. In individual plants employment practices, work rules, and so on would be determined by "co-determination", that is, consultation between the council and management, with the council having the power to veto. It was felt that this system would not only obviate the undesirable effects of the increasing size and centralization of the unions, but that labor, through the "right of co-determination", would for the first time obtain a real voice in industrial policy. Most important of all, perhaps, the council system was seen by many as providing the heart of a re-united labor movement. Since the councils would serve to represent both the economic and the political interests of labor, a purely labor political party would scarcely be necessary once the system was in operation. ${ }^{1}$

Certainly it would not require an especially acute observer to see that such a system, if instituted, would also have meant the virtual end of the trade unions. To be sure, the advocates of the councils in

${ }^{1}$ See Rudolf Rettig, Die Gewerkschaftsarbeit der KPD von 1918 bis 1925, unpubl. diss., (Hamburg, I954), pp. I-I ; Eugen Prager, Geschichte der USPD (Berlin, 1921), pp. 193-4; Baumann, p. Is. 
the USPD protested the contrary, that the institution of the council system would mean simply the "alteration" of the unions, not their complete dissolution. ${ }^{1}$ This "alteration", however, would certainly have meant radical changes in both the policies and the personnel of the union leadership. In Hamburg, the union leaders felt they had adequate proof of the meaning of the council idea in the activity of the Laufenberg Government.

As was mentioned earlier, the most significant exercise of governmental power by the Laufenberg Government after November I8, 1918, was through the new Labor Office. The activities of this office were extremely distressing for the trade union leaders in Hamburg, since Laufenberg used it primarily to stimulate the formation of works-councils throughout the large-scale industries of the city. ${ }^{2}$ For one thing, these councils acted in such a way as completely to exclude the unions from negotiations with employers. In a number of instances, Laufenberg arranged for direct negotiations between council and management to establish hours and wages and to settle other labor disputes. ${ }^{3}$

But the implications of Laufenberg's encouragement of the councils extended even further. For what his policies achieved in effect was the introduction of a new element of political and plant organization precisely among those groups where the organizational techniques of the unions and the SPD had in the past been least effective, where opposition to the unions was strongest and where the level of political participation had been lowest. The councils were an organizational nucleus around which all of the old grievances against the SPD and the trade unions might gather. On the one hand, they provided the basis of the USPD support, and on the other, the means by which the dissatisfied industrial workers might gain control of the old unions and remake them according to their own design. ${ }^{4}$ Although Laufenberg did not succeed during his term in office in building a basis of support sufficiently strong to keep him there in this way the seeds he planted grew and flourished rapidly. The council movement spread quickly throughout Hamburg's large-scale industries, forming what was later to become the basis of the Communist organization. ${ }^{5}$

${ }^{1}$ Prager, 209-I I Hamburger Volks-Zeitung, Oct. 30, I919, p. I.

2 Laufenberg, pp. 8-14.

3 Ibid.

4 The most striking instance illustrating the above points was the struggle for the leadership of the Deutsche Metallarbeiterverband in Hamburg in 1919. See Deutsche Metallarbeiterverband, Verwaltung Hamburg, Geschäftsbericht 1919, pp. 3-8; Hamburger VolksZeitung, Nov. 6, 1919, Beilage.

5 Arbeiterrat Gross-Hamburg, Jahresbericht $1919-20$, p. 59. 
Under the circumstances it is scarcely surprising that the leaders of the Free Unions took a rather dim view of this development. The basic trade union position in regard to the councils is illustrated in the statement of Carl Legien, Chairman of the Executive of the ADGB in Berlin:

"The council system would not be a feasible kind of organization... There is no purpose whatever to be served by the council system; and an incorporation of the councils into the present system of labor organizations would be unthinkable."1

The statements of the leaders of the Hamburg ADGB were similarly uncompromising in their hostility to the councils. ${ }^{2}$

Given the vigorous and readily comprehensible hostility of the unions to the council system, what possibilities were there that the SPD leadership might support such a reform? This question can to some extent be answered through a consideration of who the SPD leaders in Hamburg were and how they achieved their positions.

Turning first of all to the matter of the age of the SPD leadership, one finds that this was by no means a callow group. An examination of the list of Bürgerscbaft Members between 1919 and $1925^{3}$ shows that of 104 Members, 55 (or 53 per cent) were older than fifty years of age upon taking office; 2 I were over sixty; 4 were over seventy, and the oldest was a venerable seventy-six. The median age for SPD Bürgerschaft Members during this period was about fifty-four years.

The lists also reveal some interesting information concerning the life-work of the SPD deputies. About a third of the SPD Members had worked primarily as teachers, white-collar workers or as professional men. Another third had worked in the building trades or in printing,

${ }^{1}$ Cited in Heinz Josef Varain, Freie Gewerkschaften, Sozialdemokratie und Staat (Düsseldorf, 1956 ), p. 146.

2 See, for example, Die Freie Gewerkschaft (ADGB supplement to the Hamburger Echo), Vol. 3, Nr. 44 (I924); Hamburger Volks-Zeitung, July I, I9I9.

3 All biographical information concerning Bürgerschaft Members was taken from a manuscript in the Hamburg Staatsarchiv referred to as "Handschriftensammlung Nr. 6oI (Verzeichnis der Bürgerschaftsmitglieder aufgestellt von Franz Mönckeberg, 1959)". Since the manuscript is not paginated, references to it will be simply, "Verzeichnis". The Birgerschaft membership is a good source for studying the leadership of the parties, since the practice was to draw up party lists starting with the top local leaders and working downwards as long as the mandates lasted. The dates 1919 -25 are used for the purpose of obtaining a larger sample, although the leadership of the SPD changed only very slightly during the period. Compare the study of the national leadership of the SPD by Richard N. Hunt, The Internal Development of the SPD in the Weimar Republic, unpubl. diss. (Yale, 1958). 
and the remainder were scattered about in various trades, largely the more traditional such as tailors, bakers, goldsmiths and so on. All but a very few could indeed be classified in what is frequently referred to as the "labor aristocracy"."

By noting the specific occupation each Member listed at the time of his election, we can make some approximation of the means by which one normally achieved a leadership position in the Hamburg SPD organization. The most important "way up" for the workingclass SPD Members was clearly that of working one's way through the bureaucracy of the trade unions ( 34 per cent), the cooperatives ( 13 per cent), or one of the other miscellaneous labor organizations closely affiliated with the trade unions ( 12 per cent). In other words, some 59 per cent of these leaders had achieved their leadership positions as the product of years of diligent work in one of the labor bureaucracies. The bureaucracy of the party itself, however, was the means to the top for only about $s$ per cent of the leaders. Most of the white-collar and professional people entered the Bürgerscbaft directly from their jobs. ${ }^{2}$

Seen from the standpoint of the unions, the identity of the SPD and ADGB leadership presents a striking picture. In the Bürgerschaft elected in 19r9, for example, thirty-four of the eighty-two SPD deputies were either simultaneously trade union officials or had been until a short time before they took office. ${ }^{3}$ Eight of the twelve members of the Executive Committee of the ADGB-Hamburg, moreover, held SPD seats in the Bürgerscbaft. ${ }^{4}$

In summary it is fair to say that the leadership of the SPD consisted predominantly of men who had devoted the bulk of their lives to the trade union movement. These were men who had lived through the period of the Anti-Socialist Law and had seen the unions struggle to reach the powerful position they now held. They had with very few exceptions (none in the higher leadership) been members of the old craft unions, and most owed their political office to positions won in the unions. These were men, in other words, firmly committed to the November Agreement and the policies it implied. They were certainly not advocates of radical reform of the union organization.

1 See I. Siemann, Soziologie der Sozialdemokratischen Führerschaft I918-33 (Göttingen, r955), pp. 6r-7.

2 All of these characteristics alter radically as one moves to the left in the party line-up. The USPD leaders were younger; there were more who were members of industrial unions and fewer who had worked up through the union bureaucracy. The KPD leaders were younger still; there were no leaders from craft unions and none had worked their way up through the union buteaucracy.

3 "Verzeichnis".

4 ADGB-Hamburg, Jbrt. I920, p. 22; "Verzeichnis". 
It is rather difficult to form an exact picture of the way in which these union leaders utilized their political influence during the revolutionary days. It is certain, however, that on no occasion did the Social Democrats make an important policy decision without consulting the unions. ${ }^{1}$ Most often as on November 5, 1918, the Executive Committees of party and unions held joint sessions with a vote for each member present. ${ }^{2}$ The importance of this practice can be appreciated if one keeps in mind the extent to which the SPD leadership was itself composed of union leaders. All of the important SPD proclamations were also co-signed by the leaders of the ADGB-Hamburg. ${ }^{3}$ And, as during the discussions concerning the election of deputies to the Workers' Council, all concerned considered the ADGB and the SPD participants as forming a single group. ${ }^{4}$

Study of the history of the Council Government in Hamburg suggests a number of interesting considerations for the further study of the German Revolution as a whole. The most important of these concern the extent to which the council movement provided a real alternative to the parliamentary democracy advocated by the leaders of the SPD. Examination of the Hamburg events indicates quite clearly that the Council Government lacked the capability to provide effective government without SPD support, on the one hand, and that insur mountable difficulties, in the form of hard political realities, stood between the SPD leaders and support of the Council Government, on the other.

It seems certain, first of all, that after November 18,1918 , in Hamburg the significance of the council movement was almost entirely restricted to the sphere of labor organization. It would be difficult to make a case for the theory that Laufenberg, after consenting to the continuing existence of the Senate and Bürgerscbaft and their re-election some four months later, still hoped somehow to govern through the councils. His intention, rather, must have been to achieve a reorganization of society by means of a prior reorganization of the labor movement along the lines of a plant-based council system. ${ }^{5}$

Although the treatment in this paper has been intentionally

${ }^{1}$ For example, see Neumann, pp. 2, 19, 48ff.; SPD-Hbg., Jbrt. 1914-19, pp. 10, 2 I.

2 See Neumann, p. 2.

${ }^{3}$ For example, see Neumann, pp. 46, 59-60; Bünnemann, p. I29; SPD-Hbg., Jbrt. I9I4I9, p. I9.

4 Neumann, pp. 14-23.

5 The only work of Laufenberg's which gives any indication of what his ideas were in I918-19 is his Die Hamburger Revolution (Hamburg, 1919), but he avoids spelling them out. 
slanted somewhat in the direction of the unions, it seems equally clear that the widespread dissatisfaction with the ADGB organization was a very important factor behind the popularity of the councils. It may be recalled in this connection that the USPD lost its basis of support very quickly once it agreed to the watered-down, ADGBdominated council system which finally found its way into the statute books. ${ }^{1}$ The Communist Party, on the other hand, took up the attack on the craft unions and used it to good advantage. ${ }^{2}$

Finally, it is manifest that even if some SPD leaders in Hamburg favored the council system, as several certainly did, there was no possibility whatsoever that the party leadership could have supported it. But the problem was certainly not simply one of a lack of foresight. Rather, it is a question concerning the very nature of labor politics in Germany. There can be no doubt that the size and strength of the Hamburg SPD depended to considerable extent on the success of the union movement there. This fact was, of course, reflected in the party leadership. To suggest that the party could do without its cadre of union leaders and active supporters in the craft unions is to suggest that it should have been a different party altogether. The USPD, of course, was an attempt to form such a party based largely on the support of industrial labor, but its success was not very great.

Accepting the SPD as it was, one confronts the problem of the dogged resistance of the ADGB to organizational reform. It should be pointed out that resistance to the growth of industrial unionism has frequently been similarly determined, as in the United States. Certainly it is true that the industrial unions were more difficult to control than craft unions, and it is easy to understand the desire of the ADGB leaders to retain their own positions as well as the extensive union gains so recently won. The high degree of centralization in the German labor movement no doubt operated to render the need for reform more urgent than elsewhere, while at the same time making reform more difficult. And the high degree of political involvement characteristic of the ADGB helped to channel the opposition to the union leadership into party-political molds. It is at least a reasonable conjecture that large segments of industrial labor could have been won over to active support of the Republic through a timely and extensive reform of the organized labor movement.

${ }^{1}$ See C. W. Guillebaud, The Works Council (Cambridge, 1928); the law itself is given on pp. 249-72; Richard Seidel, The Trade Union Movement of Germany (Amsterdam, 1928), pp. Iosff.; for the opposition to the law in Hamburg, see Arbeiterrat GrossHamburg, Jahresbericht 1919-20, pp. 59ff.

2 This subject is taken up in detail, including an analysis of the electoral returns, in Comfort, op. cit. 